\title{
Utilization of Agricultural Wastes for Biogas Production
}

\author{
Egga SE1*, Azachi PB¹, Okoye MN1, Bunu GD¹, Madojutimi OE¹, \\ Abosede $\mathrm{BA}^{1}$ and Marti DM${ }^{2}$ \\ ${ }^{1}$ Department of Chemistry, Faculty of Natural Sciences, University of Jos, P.M.B \\ 2084, Jos, Plateau State, Nigeria \\ 2Department of Chemistry, Aminu Saleh College of Education, P.M.B 044, Azare, \\ Bauchi State, Nigeria
}

*Corresponding author: Samuel Egga, Department of Chemistry, Faculty of Natural Sciences, University of Jos, P.M.B 2084, Jos, Plateau State, Nigeria, Email: emmanuels@unijos.edu.ng; samegga13@gmail.com

\section{Abstract}

The study investigates the anaerobic digestion in the production of biogas from the co-digestion of three different types of agricultural wastes (Acha straws, maize stalk and maize cob) with (cow dung and goat dropping) as nutrients. All the digesters were mixed with these substrate-nutrient ratios of $4: 1$.The results obtained from the biogas production showed that the co-digestion of Digester C (maize stalk and cow dung) gave the highest yield of biogas of $280 \mathrm{ml}$, followed by the co-digestion of the four ratios, digester B maize stalk and goat dropping $260 \mathrm{ml}$, digester D (Acha straws and cow dung) of $260 \mathrm{ml}$, digester A (maize cob and cow dung) 260ml and finally digester E(maize cob and goat dropping) produced the least volume of $46 \mathrm{ml}$. The results of daily and cumulative volume of biogas produced were recorded. The rate of biogas production from these substrates and nutrients followed first order kinetics. These results show that biogas production can be enhanced from agricultural wastes.

Keywords: Anaerobic digestion; Co-digestion; Proximate analysis; Kinetics; Biogas production

\section{Introduction}

Energy consumption has increased steadily over the last century as the world population has grown and more countries have become industrialized. Biogas, a renewable biofuel is becoming increasingly important as a consequence of major concern for depleting oil reserves, rising crude oil prices and greenhouse effect. Most of the biogas plants are almost fed with cow dung, mixture of human night soil, pig dung, stacks of feed grasses, etc. The rising greenhouse gas emissions, decreasing fossil fuel supplies and energy security have led to the introduction of renewable energy targets at national level [1].

Renewable energy has remained one of the best alternatives for sustainable energy development. The energy carrier focus, in this paper, is biogas, which is among the alternatives to fossil fuels. One of the most efficient energy sources is the biogas produced from green energy crops and organic waste matters. Biogas is distinct from other renewable energies because of its 


\section{Petroleum \& Petrochemical Engineering Journal}

characteristics of using, controlling and collecting organic wastes and at the same time producing fertilizer and water for use in agricultural irrigation. Biogas does not have any geographical limitations nor does it require advanced technology for producing energy, also it is very simple to use and apply. It has a very positive impact on the environment, since less $\mathrm{CO}_{2}$ is formed during its combustion than used for photosynthesis by the plants from which it is produced [2-6].

Biogas production potential of different mixtures of unscreened dairy manure and food waste compared with the yield from manure was investigated. The methane yields of fine and coarse fractions of screened manure and unscreened manure after 30 days were 302, 228, and 241 $\mathrm{L} / \mathrm{kg}$, respectively. Approximately $93 \%, 87 \%$, and $90 \%$ of the biogas yields could be obtained after 20 days of digestion. Average methane content of the biogas was $69 \%, 57 \%$, and $66 \%$, respectively [7].

Biogas and methane yields of food and green wastes and their mixture using batch anaerobic digesters have been studied. The mixture was composed of $50 \%$ food waste and $50 \%$ green waste, based on the volatile solids initially added to the reactors. The biogas yields were found to be 430, 372 and $358 \mathrm{~mL} / \mathrm{g}$, respectively, and the methane yields were 245, 206, and $185 \mathrm{~mL} / \mathrm{g}$, respectively [8]. The production of biogas from fermentable materials such as cow dung, poultry waste and water hyacinth was studied. Percentage of methane content (the main constituent) in biogas produced from different fermentable materials was almost the same [9].

\section{Methodology}

\section{Sample Collection}

The three different plant wastes (acha straws, maize cob and maize stalk) used, were collected from their different wastes generation within Jos, Plateau state, Nigeria. The cow dung was collected from Farin gada while goat dropping was collected from Angwan Rukuba, all within Jos, Plateau State, Nigeria.

\section{Sample Preparation}

The samples were properly dried under the sun for 3 days and separated from other unwanted grasses. The dried samples were cut differently into a mortar and grounded into smaller particles after which it was blended in an electric blender to powder and followed by sieving using a local sieve to get a fine powder. The samples were kept under room temperature in dry and clean plastic bags and labeled for further use.

\section{Proximate Analysis}

Ash content, moisture content, volatile matter and fixed-carbon of the different agricultural waste (Acha straws, maize cob and maize stalk) was carried out according to AOAC [10]. These results were reported.

\section{The kinetics of biogas production}

The production of biogas followed the first order kinetics. This can be explained by showing that the rate of biogas production depends only on the concentration of one of the reactant (substrate used). Hence, can be expressed by a linear equation as shown below.

$$
\log _{10}\left(V_{\infty}-V_{t}\right)=-k / 2.303+\log _{10} V_{\infty}
$$

Where;

$\mathrm{V}_{\infty}=$ final volume of biogas produced $(\mathrm{ml})$

$\mathrm{V}_{\mathrm{t}}=$ cumulative volume of biogas at time $\mathrm{t}(\mathrm{ml})$

$\mathrm{k}=$ Rate constant per day

The rate constants and half-lives were determined and recorded.

\section{Production of Biogas}

The set up for this study was the connection of the digester to the water displacement set up. The water displacement method of gas collection is a method in which gas is allowed to replace water at equal volume of water displaced and this was used to determine the volume of biogas produced daily. A digester which consists of the prepared slurry was corked and placed in an electric water bath maintained at a temperature range of $35^{\circ} \mathrm{C}$. A short length of PVC connecting tube was used to connect the digester to an empty $500 \mathrm{ml}$ Buckner filter flask (BFF) which was also corked to prevent lost of biogas produced to the environment.

Another length of the PVC tube was connected to the outlet of the Buckner flask, such that the other end was placed under an inverted measuring cylinder filled with water in an electric water bath. The water bath was also filled with water such that the free end of the connecting tube is placed in an upward direction while under the inverted measuring cylinder. The quantity of biogas produced was measured by the downward displacement of water in an inverted water-filled measuring cylinder placed in an electrical water bath. Masking tape was used 


\section{Petroleum \& Petrochemical Engineering Journal}

to seal up all connections in order to avoid lost of gas to environment. Therefore, the quantity of biogas produced was measured and recorded. The whole set up was repeated for the other digesters. The production of biogas was monitored for 15 days at a constant temperature of $35^{\circ} \mathrm{C}$. The following slurries were made in the (substratenutrient) ratio of $4: 1$ in five digesters $(1000 \mathrm{ml}$ each) and

A- Maize cob and cow dung (4:1)

B- Maize stalk and goat dropping $(4: 1)$

C- Maize stalk and cow dung $(4: 1)$

D- Acha straws and cow dung (4:1)

E- Maize cob and goat dropping (4:1)

labeled as follows:

\section{Results and Discussion}

\begin{tabular}{|c|c|c|c|c|}
\hline S.No. & Parameter & Acha Straws (Wt \%) & Maize Cob (Wt \%) & Maize Stalk (Wt \%) \\
\hline 1 & Ash content & 5.84 & 1.1 & 5.11 \\
\hline 2 & Moisture content & 4.196 & 2.01 & 0.69 \\
\hline 3 & Volatile solid & 22 & 11 & 3.45 \\
\hline 4 & Fixed carbon & 67.964 & 85.89 & 90.75 \\
\hline
\end{tabular}

Table 1: Proximate analysis of the plant wastes.

\section{Volume of Biogas Production}
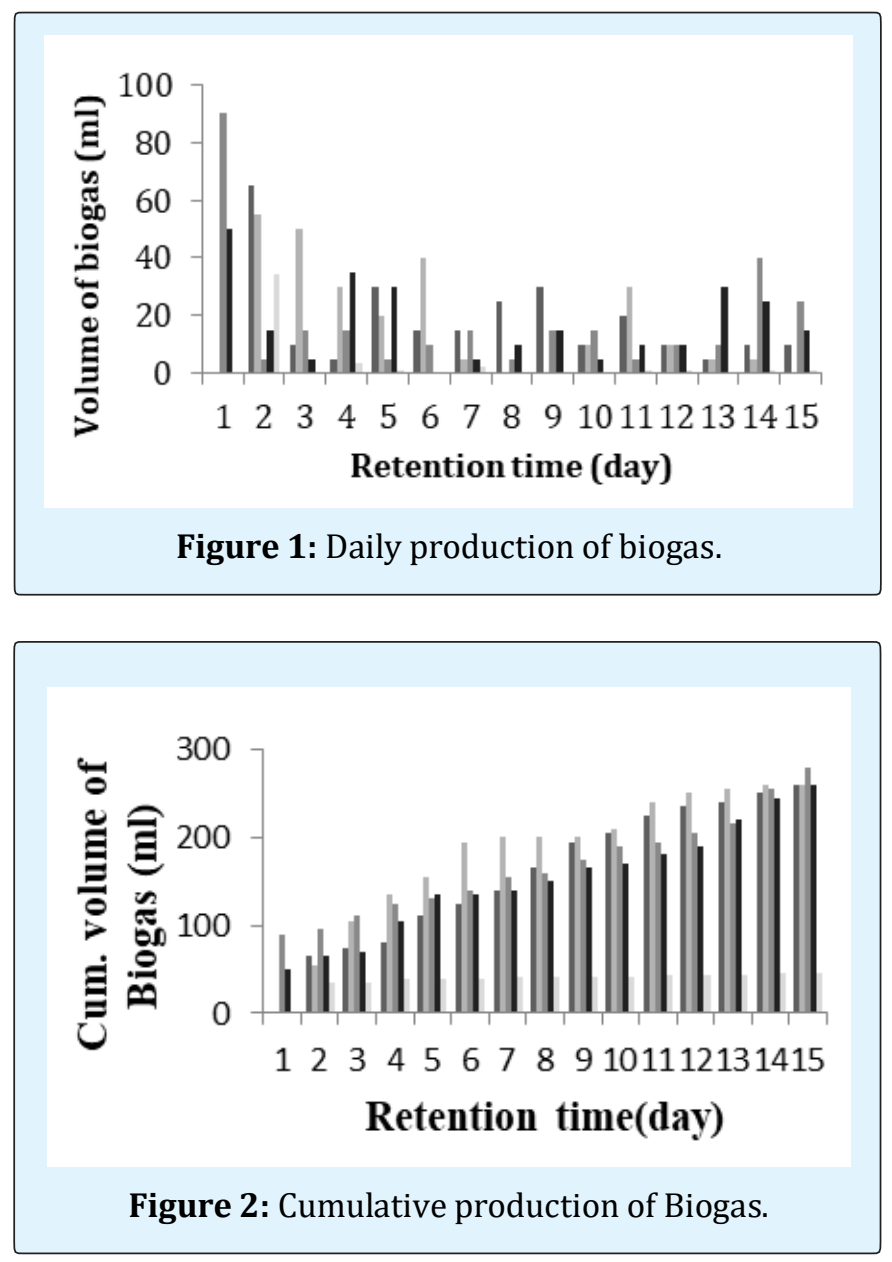

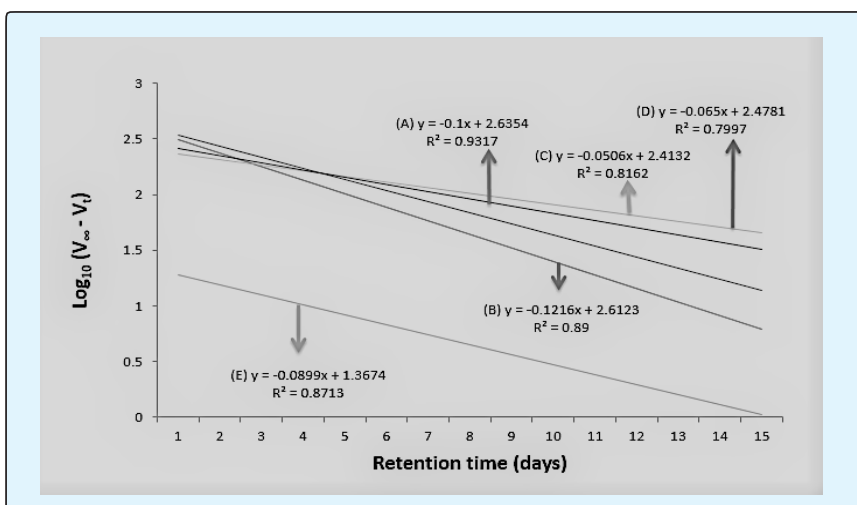

Figure 3: A graph of $\log _{10}\left(V_{\infty}-V_{t}\right)$ against time.

\begin{tabular}{|c|c|c|c|c|c|}
\hline DIGESTER & A & B & C & D & E \\
\hline Rate constant (/day) & 0.043 & 0.053 & 0.022 & 0.028 & 0.039 \\
\hline Half-life (day) & 16.12 & 13.08 & 31.5 & 24.75 & 17.77 \\
\hline
\end{tabular}

Table 2: Rate constant $(\mathrm{k})$ and half-life $\left(\mathrm{t}_{1 / 2}\right)$.

\section{Discussion}

The analysis of moisture in solid substrates is corelated with growth of microorganisms [11]. As microbes can absorb only dissolved solids, so moisture in residues provide medium for metabolic and physiological processes [12]. Volatile solids of Acha straws (22\%) were higher than that of maize cob (11\%) and maize stalk (3.45\%). ash content of acha straws (5.840\%) was found to be higher when compared with that of maize cob $(1.1 \%)$ and maize stalk (5.11\%). 


\section{Petroleum \& Petrochemical Engineering Journal}

From figure 1 above, the production of biogas from digester A (maize cob and cow dung) started on day 2 with an average volume of $65 \mathrm{ml}$, digester B (maize stalk and goat dropping) began on day 2 with an average $55 \mathrm{ml}$, digester C (maize stalk and cow dung) started on day 1 with an average volume of $90 \mathrm{ml}$, digester $\mathrm{D}$ (Acha straws and cow dung)began on day 2 with an average of $50 \mathrm{ml}$ and finally, from digester $\mathrm{E}$ (maize cob and goat dropping) began on day 2 with an average of $34.57 \mathrm{ml}$ of the retention time. Fluctuation of biogas production occurs in all the digesters which had maximum peaks different retention times. Digester A (maize cob and cow dung) had maximum biogas volume of $65 \mathrm{ml}$, digester B (maize stalk and goat droppings) had volume of $55 \mathrm{ml}$, digester $\mathrm{C}$ (maize stalk and cow dung) had a volume of $90 \mathrm{ml}$, digester $\mathrm{D}$ (Acha straws and cow dung) had maximum volume of $50 \mathrm{ml}$ and finally, digester E(maize cob and goat dropping) had a volume of $34.57 \mathrm{ml}$. After this maximum peak, there was a fluctuating decrease of biogas production in each of the co-digesters as the retention time increases [13].

Comparing the five results after 15 days has shown that, maize stalk and cow dung gave the highest cumulative yield of biogas of $280 \mathrm{ml}$, followed by maize cob and cow dung, maize stalk and goat droppings and acha straws and cow dung which had the same cumulative volume of $260 \mathrm{ml}$ and lastly, maize cob and goat dropping gave the least cumulative volume of $46 \mathrm{ml}$. From the five digesters, the digesters containing cow dung and plant wastes produced biogas faster than others. This can be attributed from the positive synergetic effects of the co-digestion of cow dung and food waste in providing more balance nutrients, increased buffering capacity and decreased effect of toxic compounds [14]. The production of biogas follows first order kinetics $[15,16]$.

\section{Conclusion}

Biogas production from co-digestion of different agricultural wastes and animal manure through anaerobic process was established to be feasible at a temperature of $35^{\circ} \mathrm{C}$.

\section{References}

1. Smyth BM, Symthm H, Murphy JD (2011) Determining the regional potential for a grass Biomethane industry. Applied Energy 88(6): 20372049.
2. Navickas K (2007) Biogas for farming, energy conversion and environment protection, International symposium, Biogas, technology and environment. University of Maribor, Faculty of Agriculture, pp: 25-29.

3. Weiland P (2003) Production and energetic use of Biogas from energy crops and wastes in Germany. Applied Biochemistry and Biotechnology 109(1-3): 263-274.

4. Chynoweth DP (2004) Biomethane from energy crops and organic wastes. Proceedings of the 10th World Congress on Anaerobic Digestion, Montreal, Canada, pp: 525-530.

5. Ploj A, Mursec B, Cus F, Zuper IU (2006) Characterization of machines for processing of waste materials. Journal of Materials Processing Technology 175(1-3): 338-343.

6. Leung DYC, Wang J (2016) An overview of biogas generation from anaerobic digestion of food waste. International Journal of Green Energy 13(2): 119131.

7. El-Mashad HM, Zhan R (2010) Biogas production from co-digestion of dairy manure and food waste. Bioresource Technology 101(11): 4021-4028.

8. Liu G, Zhang R, El-Mashad HM, Dong R (2009) Effect of feed to inoculum ratios on biogas yields of food and green wastes. Bioresource Technology 100(21): 5103-5108.

9. Imam MFIA, Khan MZH, Sarkar MAR, Ali SM (2013) Development of biogas processing from cow dung, poultry waste, and water hyacinth. International Journal of Natural and Applied Sciences 2(1): 13-17.

10. AOAC Official Methods of Analysis (1995) Association of Analytical Chemist. 17th(Edn.), Arlington Virginia.

11. Ionel I, Cioabla AE (2010) Biogas production based on agricultural residues. From history to results and perspectives. WSEAS TRANSACTIONS on ENVIRONMENT and DEVELOPMENT 8(6): 591-603.

12. Liang C (2003) The influence of temperature and moisture contents regimes on the aerobic microbial activity of a biosolids composting blend. Bioresource Technology 86(2): 131-137. 


\section{Petroleum \& Petrochemical Engineering Journal}

13. Ilaboya IR, Asekhame FF, Ezugwu MO, Erameh AA, Omofuma FE (2010) Studies on Biogas Generation from Agricultural Waste: Analysis of the Effects of Alkaline on Gas Genration. World Applied Sciences Journal 9(5): 537-545.

14. Aragaw T, Mebeaselassie A, Amare G (2013) Codigestion of cattle manure with organic kitchen waste to increase biogas production using rumen fluid as inoculums. International Journal of Physical Sciences 8(11): 443-450.
15. Usman B, Ekwenchi MM (2013) Optimum Biogas Production from Agricultural Wastes. Indian Journal of Energy 2(3): 111-115.

16. Egga SE (2015) Moderate Temperature Decomposition of Parkia biglobosa: Potentials of African Wastes. Lambert Academic Publishing, Germany. 